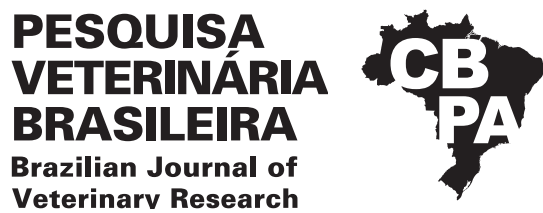

\title{
Ozonized solutions favor the repair of experimentally induced skin wounds in rats ${ }^{1}$
}

\author{
Rafael C. Sanguanini² (D), Mariana F. Bento ${ }^{3}$, Evelyn de Oliveira² ${ }^{(D)}$, \\ Emmanuel Arnhold ${ }^{4}$, Mariana B.R. Faleiro ${ }^{5}$, Leandro G. Franco ${ }^{6}$, \\ Moema P.C. Matos ${ }^{6}$ and Veridiana Maria B.D. Moura ${ }^{6 *}$
}

\begin{abstract}
Sanguanini R.C., Bento M.F., Oliveira E., Arnhold E., Faleiro M.B.R., Franco L.G., Matos M.P.C. \& Moura V.M.B.D. 2020. Ozonized solutions favor the repair of experimentally induced skin wounds in rats. Pesquisa Veterinária Brasileira 40(11):914-921. Setor de Patologia Animal, Escola de Veterinária e Zootecnia, Universidade Federal de Goiás, Avenida Esperança s/n, Campus Universitário Samambaia, Goiânia, GO 74690-900, Brazil. E-mail: vdmoura@ufg.br

This study aimed to evaluate and compare the effects of ozonized solutions on tissue wound repair in rats. Treatments consisted of ozonized water (GA), $0.9 \%$ sodium chloride (GCL), ozonized oil (GO), and $0.2 \%$ allantoin cream (GAL). The morphometric evaluation showed that wounds of the GA group presented a higher degree of retraction $(p<0.05)$ at three and eight days of treatment ( 37.96 and $84.81 \%$, respectively). Picrosirius red staining showed that groups GA and GO presented higher deposition $(\mathrm{p}<0.05)$ of type I collagen at 15 and 22 days of treatment, respectively. The neovascularization was higher in wounds of group GO on days 3,8 , and $15(\mathrm{p}<0.05)$, with higher VEGF immunostaining. $(\mathrm{p}<0.05)$. Thus, ozonized water enhances wound retraction and assists in the maturation and remodeling phase, while ozonized oil promotes higher neovascularization during tissue repair and higher deposition of type I collagen from the third week of treatment.
\end{abstract}

INDEX TERMS: Ozonized water, wound healing, ozonized oil, ozone therapy, skin wounds, rats.

RESUMO.- [Soluções ozonizadas favorecem o reparo de feridas cutâneas experimentalmente induzidas em ratos.] O objetivo deste estudo foi avaliar e comparar os efeitos de soluções ozonizadas sobre o reparo tecidual de feridas em

\footnotetext{
${ }^{1}$ Received on August 1, 2020.

Accepted for publication on August 14, 2020.

${ }^{2}$ Graduate Program in Animal Science (PPGCA), Escola de Veterinária e Zootecnia (EVZ), Universidade Federal de Goiás (UFG), Avenida Esperança s/n, Campus Universitário Samambaia, Goiânia, GO 74690-900, Brazil.

${ }^{3}$ Graduação em Medicina Veterinária (Bolsista PIBIC/CNPq), Escola de Veterinária e Zootecnia (EVZ), Universidade Federal de Goiás (UFG), Avenida Esperança s/n, Campus Universitário Samambaia, Goiânia, G0 74690-900, Brazil.

${ }^{4}$ Departamento de Zootecnia, Escola de Veterinária e Zootecnia (EVZ), Universidade Federal de Goiás (UFG), Avenida Esperança s/n, Campus Universitário Samambaia, Goiânia, GO 74690-900, Brazil.

${ }^{5}$ Faculdade de Odontologia (FO), Universidade Federal de Goiás (UFG), Av. Universitária esquina com 1를 Avenida s/n, Setor Leste Universitário, Campus Colemar Natal e Silva, Goiânia, GO 74605-220, Brazil.

${ }^{6}$ Departamento de Medicina Veterinária, Escola de Veterinária e Zootecnia (EVZ), Universidade Federal de Goiás (UFG), Avenida Esperança s/n, Campus Universitário Samambaia, Goiânia, GO 74690-900, Brazil. *Corresponding author: vdmoura@ufg.br
}

ratos. Foram realizados os tratamentos: água ozonizada (GA), cloreto de sódio 0,9\% (GCL), óleo ozonizado (GO) e creme de alantoína 0,2\% (GAL). À avaliação morfométrica, as feridas do grupo GA apresentaram maior grau de retração $(\mathrm{p}<0,05)$ aos três e oito dias de tratamento $(37,96 \%$ e $84,81 \%$, respectivamente). A coloração de picrosirius red mostrou que os grupos GA e GO apresentaram maior deposição $(\mathrm{p}<0,05)$ de colágeno do tipo I aos 15 e aos 22 dias de tratamento, respectivamente. Já a variável neovascularização foi maior $(\mathrm{p}<0,05)$ nas feridas do grupo GO nos dias três, oito e 15, o que fora ratificado à imuno-histoquímica, com maior imunomarcação de VEGF nas feridas do grupo GO $(p<0,05)$. Conclui-se que a água ozonizada potencializa a retração da ferida e auxilia na fase de maturação e remodelamento, enquanto o óleo ozonizado promove maior neovascularização durante o reparo tecidual e maior deposição de colágeno do tipo I a partir da terceira semana de tratamento.

TERMOS DE INDEXAÇÃO: Água ozonizada, cicatrização, óleo ozonizado, ozonioterapia, feridas cutâneas, ratos. 


\section{INTRODUCTION}

Ozone therapy has been used in the adjunctive treatment of wounds, assisting tissue repair in an economically viable, non-invasive way without side effects (Haddad et al. 2009). Ozone is an unstable molecule with a strong oxidizing effect that eliminates microorganisms without causing resistance (Yucesoy et al. 2017) and improves local inflammatory response by stimulating the synthesis and release of cytokine and growth factors, such as epidermal growth factor (EGF), platelet-derived growth factor (PDGF), transforming growth factor (TGF), and vascular endothelial growth factor (VEGF) (Araneda et al. 2008, Valacchi et al. 2011).

Ozone is used to treat skin wounds in gaseous form or dissolved in water or oil (ozonized solutions). The use of ozonized solutions has the advantage of reducing the risks associated with ozone inhalation, besides establishing the ideal humid environment to facilitate the interaction between ozone and biomolecules. Ozonized water is easy to handle and apply in hard-to-reach places, but dissolved ozone degrades rapidly, implying immediate use of water after ozonation. Oil diffuses ozone molecules slowly to the tissue due to its ability to stabilize the gas (Sechi et al. 2011, Valacchi et al. 2011).

Although ozonized solutions aid tissue repair, there is no standardized protocol for the treatment of skin wounds or even comparative studies to evaluate the advantages and disadvantages of these solutions. Therefore, this study aimed to verify the effects of ozonized water and oil on experimentally induced skin wounds in rats to establish a viable experimental protocol for clinical application, elucidating which aspects of tissue repair it is advantageous to use each of the ozonized solutions.

\section{MATERIALS AND METHODS}

This research was authorized by the Animal Use Ethics Committee (CEUA) of the "Universidade Federal de Goiás" (UFG) under protocol 079/2017. Forty-eight female Wistar albino rats (Rattus norvegicus) weighing from 250 to $300 \mathrm{~g}$, provided by the UFG Central Vivarium, were used. Two animals were placed per box, being separated by a transparent acrylic plate, in a sanitized, air-conditioned environment $\left(23^{\circ} \mathrm{C}\right)$, with a 12 -hour light cycle (light/dark) and both water and commercial feed ad libitum. The animals remained in the adaptation period for ten days before the beginning of the experiment.

Animals were randomly placed into four groups of 12 individuals each, according to the following treatments: ozonized water (GA), ozonized sunflower oil (GO), $0.9 \%$ sodium chloride (GCL), and $0.2 \%$ allantoin cream (GAL). Three animals from each group were euthanized on days $3,8,15$, and 22 after wound induction for sample collection and microscopic analysis.

Ozonized water was produced with an O\&L 1.5RM ozone generator (Ozone \& Life, São José dos Campos, São Paulo, Brazil). For this, a $100 \mathrm{~mL}$ beaker was filled with $50 \mathrm{~mL}$ of deionized bidistilled water at $7^{\circ} \mathrm{C}$, which was ozonized by bubbling for 15 minutes with the equipment adjusted to produce $62 \mathrm{mcg} / \mathrm{mL}$ of ozone. The protocol used allowed reaching the final concentration of $4.5 \mathrm{mcg}$ of ozone per mL of water (Bocci 2005), as verified by the Vacu-Vials Ozone 0-5ppm test (CHEMetrics Inc., Midland, Virginia, USA).

Ozonized sunflower oil was purchased commercially (Ozone \& Life, São Jose dos Campos, São Paulo, Brazil), with a peroxide index of $418.48 \mathrm{mEq} / \mathrm{kg}$. The $0.2 \%$ allantoin cream used in the wound of the positive control animals was also commercially purchased (Interdrogas, Goiânia, Goiás, Brazil), as well as the $0.9 \%$ sodium chloride (Laboratório Arboreto, Juiz de Fora, Minas Gerais, Brazil) used in the wound of animals of the negative control group.

Animals underwent isoflurane inhalation anesthetic protocol for wound induction. After trichotomy and antisepsis, a single wound was made using a $9 \mathrm{~mm}$ diameter metal punch on the dorsal region of the animals, between the two scapulae, from which a skin fragment plus the epidermis, dermis, and subcutaneous tissue were removed.

Treatments were performed once a day until the animals were euthanized $(3,8,15$, and 22 days after wound induction). The wound of GA group animals was irrigated with $3 \mathrm{~mL}$ of ozonized water for 30 seconds immediately after its ozonation. A new ozonation protocol was performed every three animals treated in order to lessen the impact of ozone depletion on water. The wound of GCL group animals was irrigated with $0.9 \%$ sodium chloride, following the same procedure as those used in the groups treated with ozonized water. The wound of GO group animals was treated with $50 \mu \mathrm{L}$ of ozonized oil, and that of GAL group animals received $150 \mathrm{mg}$ of $0.2 \%$ allantoin cream on the wound area.

Wound retraction was evaluated on days zero (surgery day), 3, 8, 15 , and 22 days after wound induction. Wounds were photographed with a camera (Sony ${ }^{\circledR}$ SLT-A35), and the images were exported to the image-processing program Image J (NIH) version 1.3.1, which allowed demarcating wound boundaries were demarcated and measuring wound area $\left(\mathrm{mm}^{2}\right)$. The degree of wound retraction was calculated from values transformed into a percentage according to the equation:

$$
\text { DWR }=\frac{\left(\text { IWA }-W^{\mathrm{N}}\right)}{\text { IWA }} \times 100
$$

Where DWR is the degree of wound retraction, IWA is the initial wound area, and $\mathrm{WA}^{\mathrm{N}}$ is the wound area on the day the photograph was taken ( $\mathrm{N}=$ days $3,8,15$, or 22$)$.

Microscopic evaluation was performed by taken a rectangular skin fragment of each animal, including the entire lesion area and the edges of the adjacent normal tissue $(1 \mathrm{~cm}$ of the border). These fragments were fixed in $10 \%$ buffered formalin for 48 hours and then transferred to $70 \%$ alcohol solution, where they remained until the histological processing and paraffin inclusion. Histological sections of $5 \mu \mathrm{m}$ were distended on glass slides and stained with hematoxylin and eosin (HE).

The analysis of histomorphological variables was performed observing parameters that included reepithelialization, type of extracellular matrix (ECM), neovascularization, acanthosis, polymorphonuclear infiltrate, mononuclear infiltrate, and edema. Scores from zero to 3 were assigned to the reepithelization, as described by Silva et al. (2016). Scores from 1 to 3 were assigned for the type of ECM, where score one represented a vascular ECM with high number of newly formed vessels and immature fibroblasts and discrete deposition of weakly stained, sparse collagen fibers with a wavy appearance; score two represented the fibrovascular ECM with newly formed vessels, immature and mature fibroblasts, moderate deposition of more clustered and eosinophilic collagen fibers, and, sometimes, linear in appearance; and score three represented a fibrous ECM, typified by a marked deposition of markedly thick, compactly aligned eosinophilic collagen fibers, with mature fibroblasts and few vessels. A quantitative approach was performed for the variable neovascularization by calculating the average of blood vessels (tubular structures with endothelium and red blood cells in the lumen) in ten fields using a 40x objective, according to criteria adapted from Valacchi et al. (2011). The scores 
zero (absent), one (discrete), two (moderate), and three (marked) were assigned for the other variables.

Histological slides were made and submitted picrosirius red staining for collagen fiber quantification. Photomicrographs of ten fields were captured under the $40 \mathrm{x}$ objective using a polarized light optical microscope and a camera (Sony ${ }^{\circledR}$ NEX-3) attached. The images were analyzed using the software Image $\mathrm{J}(\mathrm{NIH})$ version 1.3.1 through the color threshold tool to show the percentage of area occupied by type I and III collagen fibers (Brassolatti et al. 2016). This tool allows identify and differentiate the birefringence of collagen fibers, which is related to their morphological conformation. Thus, type I collagen fibers have strong birefringence, emitting a glow that varies from orange yellow to red, while type III emits a greenish glow. The total fibers were obtained by simultaneous disclosure in the Image J of areas occupied by type I and III collagen fibers.

Histological sections were distended on charged slides (Starfrost, Knittel Glass, Germany) for VEGF immunostaining (immunohistochemistry - IHC). The sections were immersed in blocking solutions of endogenous peroxidase and background proteins after the deparaffinization, hydration, and antigen recovery steps. Samples were incubated for 18 hours with primary anti-VEGF antibody (sc-53462 - Santa Cruz Biotechnology, Inc.) at a concentration of 1:100. The sections were then washed and incubated with secondary antibody and N-Histofine ${ }^{\circledR}$ Simple Stain Rat MAX PO (MULTI) reaction amplifier (Nichirei Biosciences Inc., Tokyo, Japan). The diaminobenzidine solution counterstained with Mayer's Hematoxylin was used for reaction visualization. The scores one (discrete), two (moderate), and three (marked) were assigned to immunostaining intensity.

Shapiro-Wilk test was used to verify residual abnormality. Due to non-normality, the Kruskal-Wallis nonparametric test at 5\% significance was used to compare treatments at each moment of the macroscopic morphometric evaluation and during the analysis of microscopic parameters to histopathological and immunohistochemical examinations. The t-test with FDR adjustment was performed as a post-test. The results of the analyses of collagen quantification were subjected to analysis of variance and the means compared by the Duncan test. For this, the R software and the R easy ANOVA package (Arnhold 2013) were used.

\section{RESULTS}

The macroscopic morphometric evaluation showed that the wound of GA animals presented higher retraction in relation to that of animals of other groups (Table 1) at all evaluation moments, except on day 22, when all the wounds were closed. The wound in rats of GA and GCL groups had significantly higher retraction $(\mathrm{p}<0.05)$ compared to that of animals of groups GO and GAL on day 3. On day 8 (Fig.1), wound retraction of GA rats remained higher than that of groups GO and GAL, which statistically equaled the retraction observed in GCL animals.

Table 1. Means, medians and ranks sums, respectively, referring to the percentage of skin wound retraction in rats submitted to different treatments at $3,8,15$, and 22 days after the surgical procedure

\begin{tabular}{lcccc}
\hline \multirow{2}{*}{ Group } & \multicolumn{4}{c}{ Period } \\
\cline { 2 - 5 } & 3 days & 8 days & 15 days & 22 days* $^{*}$ \\
\hline GA & $37.6 / 37.9 / 35.3^{\mathrm{a}}$ & $84.9 / 84.8 / 27.2^{\mathrm{a}}$ & $100 / 100 / 14.0^{\mathrm{a}}$ & $100^{\mathrm{a}}$ \\
GCL & $33.4 / 33.1 / 29.5^{\mathrm{a}}$ & $78.1 / 80.2 / 20.4^{\mathrm{ab}}$ & $99.5 / 100 / 12.3^{\mathrm{a}}$ & $100^{\mathrm{a}}$ \\
GO & $22.6 / 24.4 / 16.8^{\mathrm{b}}$ & $69.8 / 72.7 / 14.0^{\mathrm{b}}$ & $98.2 / 100 / 11.8^{\mathrm{a}}$ & $100^{\mathrm{a}}$ \\
GAL & $21.9 / 22.6 / 16.3^{\mathrm{b}}$ & $62.4 / 66.7 / 12.3^{\mathrm{b}}$ & $98.2 / 100 / 11.8^{\mathrm{a}}$ & $100^{\mathrm{a}}$
\end{tabular}

a,b,ab Within the same period, a value is only statistically different from another if there are no equal letters. A value identified as "a" is different from a value identified as " $b$ ", but not from a value identified as "ab", by the Kruskal-Wallis test $(\mathrm{p}<0.05)$; *At 22 days after the surgical procedure, all rats showed $100 \%$ wound retraction. Thus, the tests were not applied because all values are equal and therefore, there is no difference to be tested; GA = ozonized water group, GCL = sodium chloride group, GO = ozonized oil group, $\mathrm{GAL}=$ allantoin group .
GA
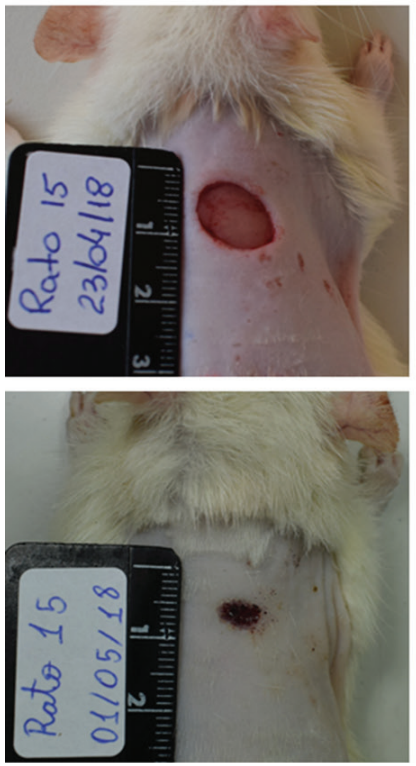

GCL
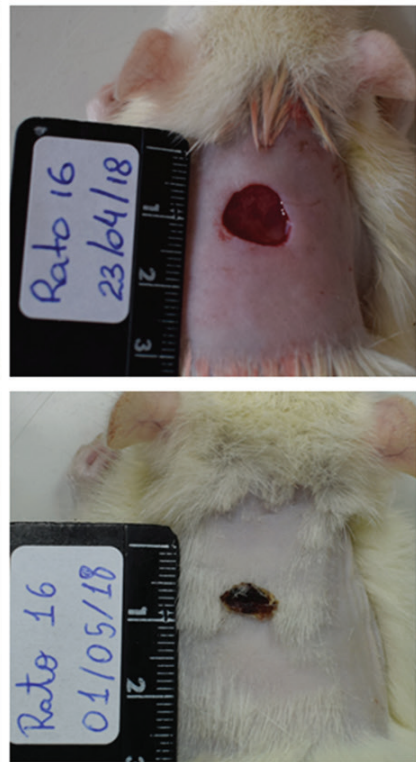

GO
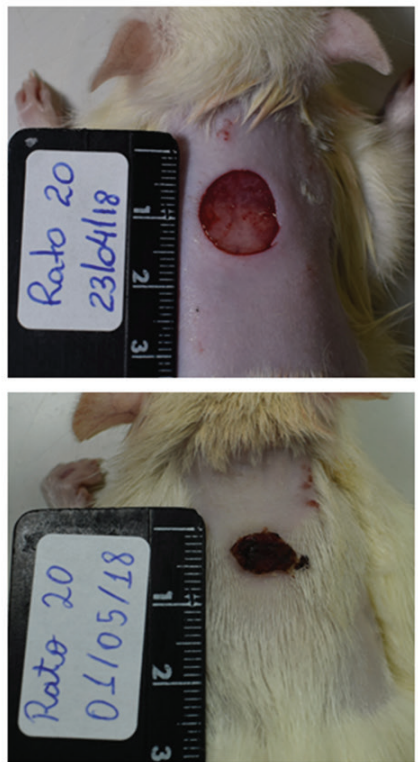

GAL

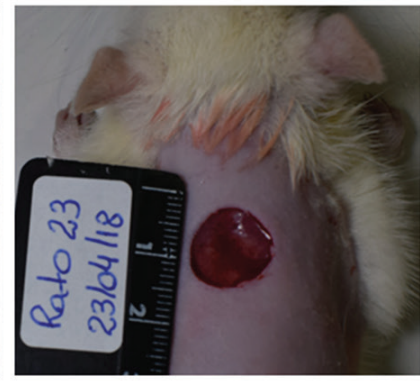

DAY 0

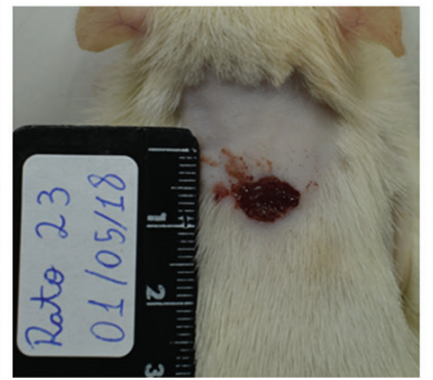

DAY 8

Fig.1. Wound on the back of rats of groups ozonized water (GA), $0.9 \%$ sodium chloride (GCL), ozonized oil (GO), and 0.2\% allantoin cream (GAL) on days zero (upper) and eight (lower) after injury induction. Wounds of similar size to day zero in all groups; the GA rat wound exhibits greater retraction at 8 days after injury induction when compared to that of the other groups. 
The variables polymorphonuclear infiltrate, mononuclear infiltrate, edema, type of ECM, reepithelization, and acanthosis, had no differences ( $p>0.05$ ) between treatments of groups $G A$, GCL, GO, and GAL. Regarding neovascularization, the wound of GO rats presented the highest blood vessel count at all evaluated times, while GCL had the lowest count (Table 2). The wound of GO animals on day three was significantly more vascularized $(\mathrm{p}<0.05)$ than that of GCL animals. At 8 days, the wounds of groups GO and GAL stood out $(\mathrm{p}<0.05)$ in relation to those of GCL group, while at 15 days, the wounds of rats of GCL and GAL groups had the lowest vessel counts, with a difference between them and GO (Fig.2). At 22 days, the wounds of GA group animals presented the lowest neovascularization $(p<0.05)$ when compared to those from the other groups.

The microscopic analysis with picrosirius red staining (Fig.3) at eight days showed that the wound of animals from groups GA and GCL had higher total collagen fibers than that observed for GAL rats $(\mathrm{p}<0.05)$ (Table 3$)$. The percentage of type I and III collagen fibers (Table 4) in relation to total collagen showed that the wound of GA rats presented a higher amount $(\mathrm{p}<0.05)$ of more resistant collagen fibers (type I) at 15 days than that found for GAL animals. At 22 days, the wound of GO rats had a higher amount of resistant fibers when compared to groups GA and GAL.

Table 2. Means, medians and ranks sums, respectively, of neovascularization in the skin wound of rats at $3,8,15$, and 22 days after induction and treatment with ozonized water (GA), sodium chloride (GCL), ozonized oil (GO), and allantoin (GAL)

\begin{tabular}{lcccc}
\hline \multirow{2}{*}{ Group } & \multicolumn{4}{c}{ Period } \\
\cline { 2 - 5 } & 3 days & 8 days & 15 days & 22 days \\
\hline GA & $9.33 / 9 / 5.16^{\mathrm{ab}}$ & $18.66 / 19 / 6.50^{\mathrm{ab}}$ & $10.00 / 10 / 6.00^{\mathrm{ab}}$ & $6.33 / 6 / 2.00^{\mathrm{b}}$ \\
GCL & $8.33 / 8 / 3.50^{\mathrm{b}}$ & $14.66 / 14 / 2.33^{\mathrm{b}}$ & $9.33 / 9 / 4.50^{\mathrm{b}}$ & $8.66 / 9 / 7.66^{\mathrm{a}}$ \\
GO & $11.00 / 11 / 9.50^{\mathrm{a}}$ & $20.33 / 20 / 9.00^{\mathrm{a}}$ & $14.00 / 13 / 10.66^{\mathrm{a}}$ & $8.66 / 9 / 7.66^{\mathrm{a}}$ \\
GAL & $10.66 / 10 / 7.83^{\mathrm{ab}}$ & $20.00 / 20 / 8.16^{\mathrm{a}}$ & $9.33 / 9 / 4.50^{\mathrm{b}}$ & $8.50 / 8.5 / 7.00^{\mathrm{a}}$
\end{tabular}

a,b,ab Within the same period, a value is only statistically different from another if there are no equal letters. Thus, a value identified as " $a$ " is different from a value identified as " $b$ ", but not from a value identified as "ab", by the Kruskal-Wallis test $(\mathrm{p}<0.05)$.
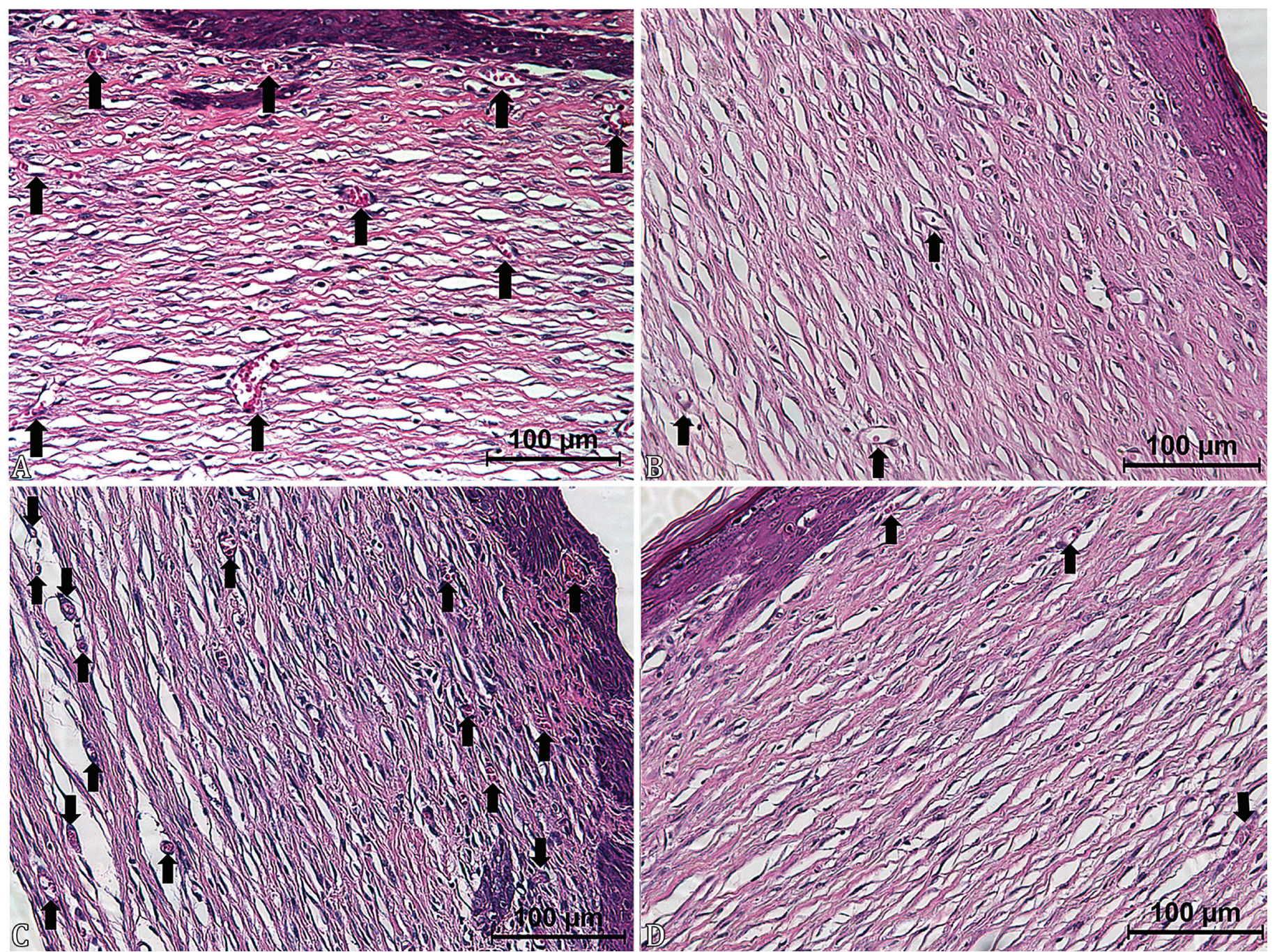

Fig.2. Photomicrographs of the skin of rats from different groups at 15 days after wound induction, showing newly formed vessels (arrows). (A) Group ozonized water (GA) showing moderate neovascularization. HE, obj.40x. (B) Group 0.9\% sodium chloride (GCL) showing discreet neovascularization. HE, obj.40x. (C) Group ozonized oil (GO) showing marked neovascularization. HE, obj.40x. (D) Group 0.2\% allantoin cream (GAL) showing discreet neovascularization. HE, obj.40x. 
Immunostaining of vascular endothelium, inflammatory cells, fibroblasts, and, in some cases, epithelial cells were observed in the immunohistochemical evaluation of VEGF (Fig.4). The wound of GO rats presented higher VEGF immunostaining than that observed in animals of other groups (Table 5). Wounds of GO animals showed a higher VEGF immunostaining when compared to those of GCL rats at 8 and 22 days and those of GA animals at 15 and 22 days. Although the wound of GO rats showed higher medians than those observed in GAL animals, no difference was found between these groups at all evaluated times.

\section{DISCUSSION}

Ozonized water promoted the highest percentage of retraction of skin wounds at all evaluated times. Wounds of GA presented higher retraction when compared to those of groups GO and GAL 3 and 8 days after wound induction $(\mathrm{p}<0.05)$, and better numerical results compared to those of GCL. Similarly, Filippi (2001) treated wounds in the oral mucosa of humans and found that ozonized water at concentrations of 11 to $12 \mathrm{mcg} /$ $\mathrm{mL}$ induced higher rates of wound retraction in the first seven days of analysis. Another study showed that ozonized water at a concentration of $0.1 \mathrm{mcg} / \mathrm{mL}$ could accelerate the regeneration process in zebrafish undergoing caudal fin amputation (Hao et al. 2015). These results demonstrate that ozonized water has a wide dose range, with positive effects on tissue repair. In this sense, the ozone concentration of $4.5 \mathrm{mcg} /$ $\mathrm{mL}$ used in this study and obtained from that described by Bocci (2005) is in the mentioned range of beneficial effects, being considered efficient in helping the repair of induced wounds in rats. It is in accordance with the information of this author when referring that concentrations of $5 \mathrm{mcg} / \mathrm{mL}$
Table 3. Means of collagen fibers in rat skin wounds at 8 , 15, and 22 days after induction and treatment in groups GA, GCL, GO, and GAL

\begin{tabular}{lccc}
\hline \multirow{2}{*}{ Group } & \multicolumn{3}{c}{ Period } \\
\cline { 2 - 4 } & 8 days & 15 days & 22 days \\
\hline GA & $4.71^{\mathrm{a}}$ & $20.54^{\mathrm{a}}$ & $22.87^{\mathrm{a}}$ \\
GCL & $6.67^{\mathrm{a}}$ & $15.51^{\mathrm{a}}$ & $21.06^{\mathrm{a}}$ \\
GO & $3.66^{\mathrm{ab}}$ & $10.73^{\mathrm{a}}$ & $25.12^{\mathrm{a}}$ \\
GAL & $1.29^{\mathrm{b}}$ & $10.17^{\mathrm{a}}$ & $24.03^{\mathrm{a}}$
\end{tabular}

a,bab Within the same period, a value is only statistically different from another if there are no equal letters. Thus, a value identified as "a" is different from a value identified as " $b$ ", but not from a value identified as "ab", by the Duncan test $(\mathrm{p}<0.05) ; \mathrm{GA}=$ ozonized water group, $\mathrm{GCL}=$ sodium chloride group, $\mathrm{GO}=$ ozonized oil group, $\mathrm{GAL}=$ allantoin group

Table 4. Mean percentage of type I and III collagen fibers in relation to total collagen in wounds at 8,15 , and 22 days after induction in groups GA, GCL, GO, and GAL

\begin{tabular}{lccccc}
\hline \multirow{2}{*}{ Period } & $\begin{array}{c}\text { Collagen } \\
\text { fiber }\end{array}$ & GA & GCL & GO & GAL \\
\cline { 3 - 6 } 8 days & I & $77.33^{\mathrm{a}}$ & $75.93^{\mathrm{a}}$ & $50.10^{\mathrm{a}}$ & $54.83^{\mathrm{a}}$ \\
& III & $22.67^{\mathrm{A}}$ & $24.07^{\mathrm{A}}$ & $49.90^{\mathrm{A}}$ & $45.17^{\mathrm{A}}$ \\
\multirow{2}{*}{15 days } & I & $93.46^{\mathrm{a}}$ & $88.83^{\mathrm{ab}}$ & $84.60^{\mathrm{ab}}$ & $82.10^{\mathrm{b}}$ \\
& III & $6.54^{\mathrm{B}}$ & $11.17^{\mathrm{AB}}$ & $15.40^{\mathrm{AB}}$ & $17.90^{\mathrm{A}}$ \\
22 days & I & $84.59^{\mathrm{b}}$ & $86.49^{\mathrm{ab}}$ & $90.20^{\mathrm{a}}$ & $84.41^{\mathrm{b}}$ \\
& III & $15.41^{\mathrm{A}}$ & $13.51^{\mathrm{AB}}$ & $9.80^{\mathrm{B}}$ & $15.59^{\mathrm{A}}$
\end{tabular}

a,b,ab Within the same period, groups followed by the same lowercase letter have statistically equal means (considering type I collagen fibers); $\mathrm{A}, \mathrm{B}, \mathrm{AB}$ within the same period, groups followed by the same uppercase letter have statistically equeal means (considering type III collagen fibers); For these comparisons, Duncan test was used $(\mathrm{p}<0.05)$; GA = ozonized water group, GCL = sodium chloride group, $\mathrm{GO}=$ ozonized oil group, $\mathrm{GAL}=$ allantoin group.
GA
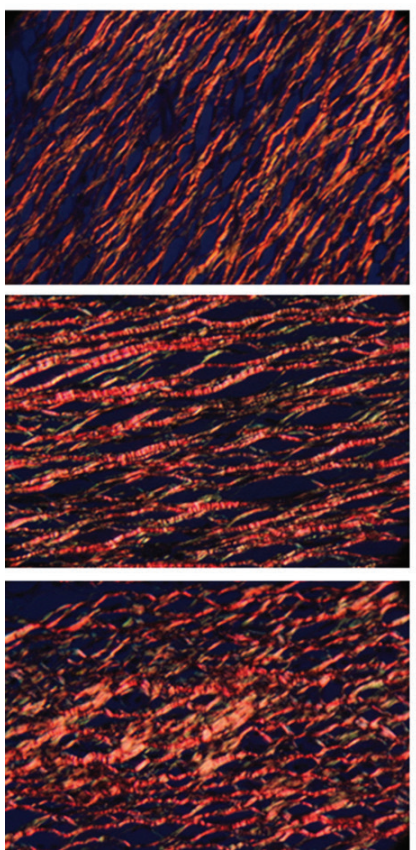

GCL
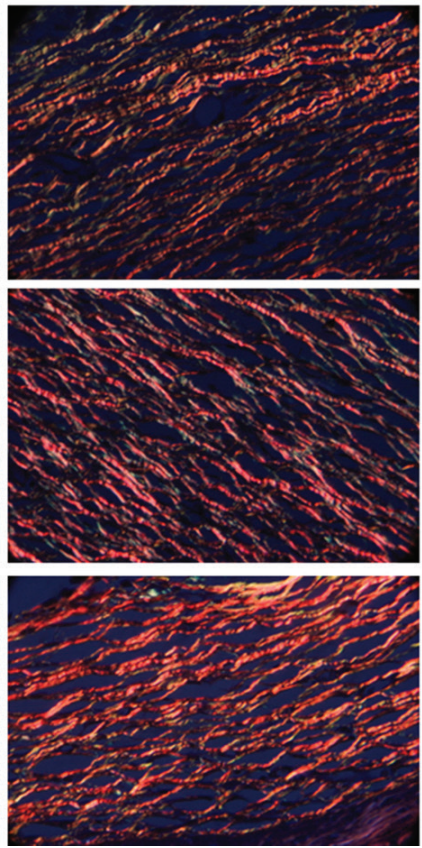

GO
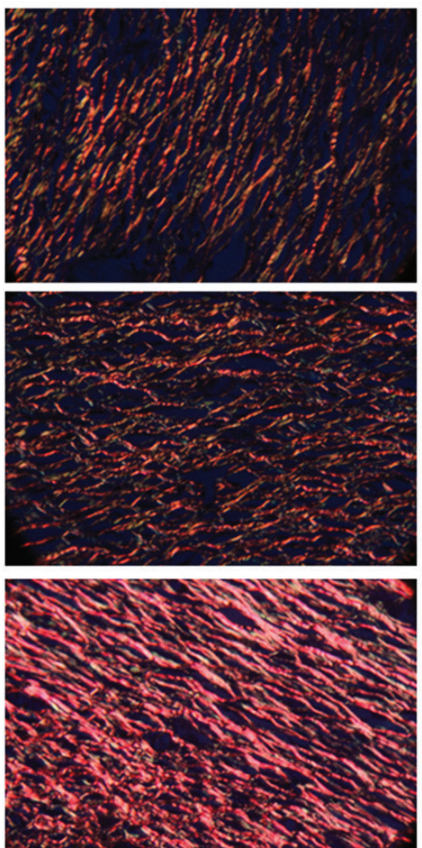

GAL

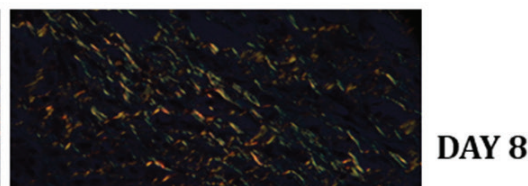

DAY 8
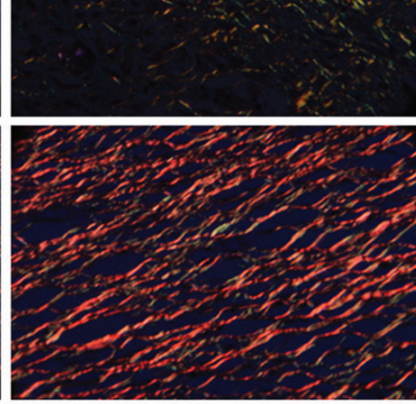

DAY 15

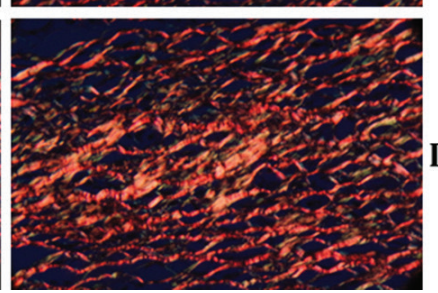

Fig.3. Photomicrographs of rat skin showing type I and III collagen fibers at 8, 15, and 22 days after induction in groups ozonized water (GA), $0.9 \%$ sodium chloride (GCL), ozonized oil (GO), and $0.2 \%$ allantoin cream (GAL). Picrosirius red, obj.40x. 
of ozone in the water are ideal for helping the proliferation and remodeling phases of skin wounds.

Wounds that received ozonized oil with a peroxide index of $418.48 \mathrm{mEq} / \mathrm{kg}$ showed an average wound retraction of $69.84 \%$ at 8 days of treatment compared to its original size, a

Table 5. Means, medians and ranks sums, respectively, of VEGF immunostaining in the skin wound of rats at $3,8,15$, and 22 days after induction in groups GA, GCL, G0, and GAL

\begin{tabular}{lcccc}
\hline \multirow{2}{*}{ Group } & \multicolumn{4}{c}{ Period } \\
\cline { 2 - 5 } & 3 days & 8 days & 15 days & 22 days \\
\hline GA & $1.33 / 1 / 6.50^{\mathrm{a}}$ & $2.66 / 3 / 6.67^{\mathrm{ab}}$ & $1.00 / 1 / 3.00^{\mathrm{b}}$ & $0.66 / 1 / 5.33^{\mathrm{b}}$ \\
GCL & $1.00 / 1 / 4.50^{\mathrm{a}}$ & $2.00 / 2 / 3.00^{\mathrm{b}}$ & $1.66 / 2 / 6.66^{\mathrm{ab}}$ & $0.33 / 0 / 3.66^{\mathrm{b}}$ \\
GO & $1.66 / 2 / 8.50^{\mathrm{a}}$ & $3.00 / 3 / 8.50^{\mathrm{a}}$ & $2.33 / 2 / 9.66^{\mathrm{a}}$ & $1.66 / 2 / 10.0^{\mathrm{a}}$ \\
GAL & $1.33 / 1 / 6.50^{\mathrm{a}}$ & $3.00 / 3 / 7.83^{\mathrm{ab}}$ & $1.66 / 2 / 6.66^{\mathrm{ab}}$ & $1.00 / 1 / 7.00^{\mathrm{ab}}$
\end{tabular}

a,b,ab Within the same period, a value is only statistically different from another if there are no equal letters. Thus, a value identified as "a" is different from a value identified as " $b$ ", but not from a value identified as "ab", by the Kruskal-Wallis test ( $\mathrm{p}<0.05) ; \mathrm{GA}=$ ozonized water group, GCL = sodium chloride group, $\mathrm{GO}=$ ozonized oil group, $\mathrm{GAL}=$ allantoin group. value below that presented by GA. Other studies have shown that wounds treated with ozonized oil had a higher retraction in the first days of treatment compared to those receiving oil only, and the retraction process was complete from nine days after injury (Kim et al. 2009, Xiao et al. 2017). These findings have been confirmed by studies using ozonized oil with peroxide concentrations between 700 and $1631 \mathrm{mEq} / \mathrm{kg}$, which also reported higher wound retraction rates (Valacchi et al. 2011, Pai et al. 2014). In contrast, one of these studies (Pai et al. 2014) found that oil at $500 \mathrm{mEq} / \mathrm{kg}$ of peroxide does not change the wound retraction rate compared to pure oil and commercial healing cream, while the other study (Valacchi et al. 2011) reports that a concentration of $3170 \mathrm{mEq} / \mathrm{kg}$ of peroxides also does not promote positive effects on wound retraction. In this context, the oil peroxide concentration used in this research justifies the performance of the GO group below expectations regarding the aspect of wound retraction.

In addition, there is another reference for wounds treated with ozonized oil, showing no difference in retraction compared to control groups. However, peroxide concentration was not
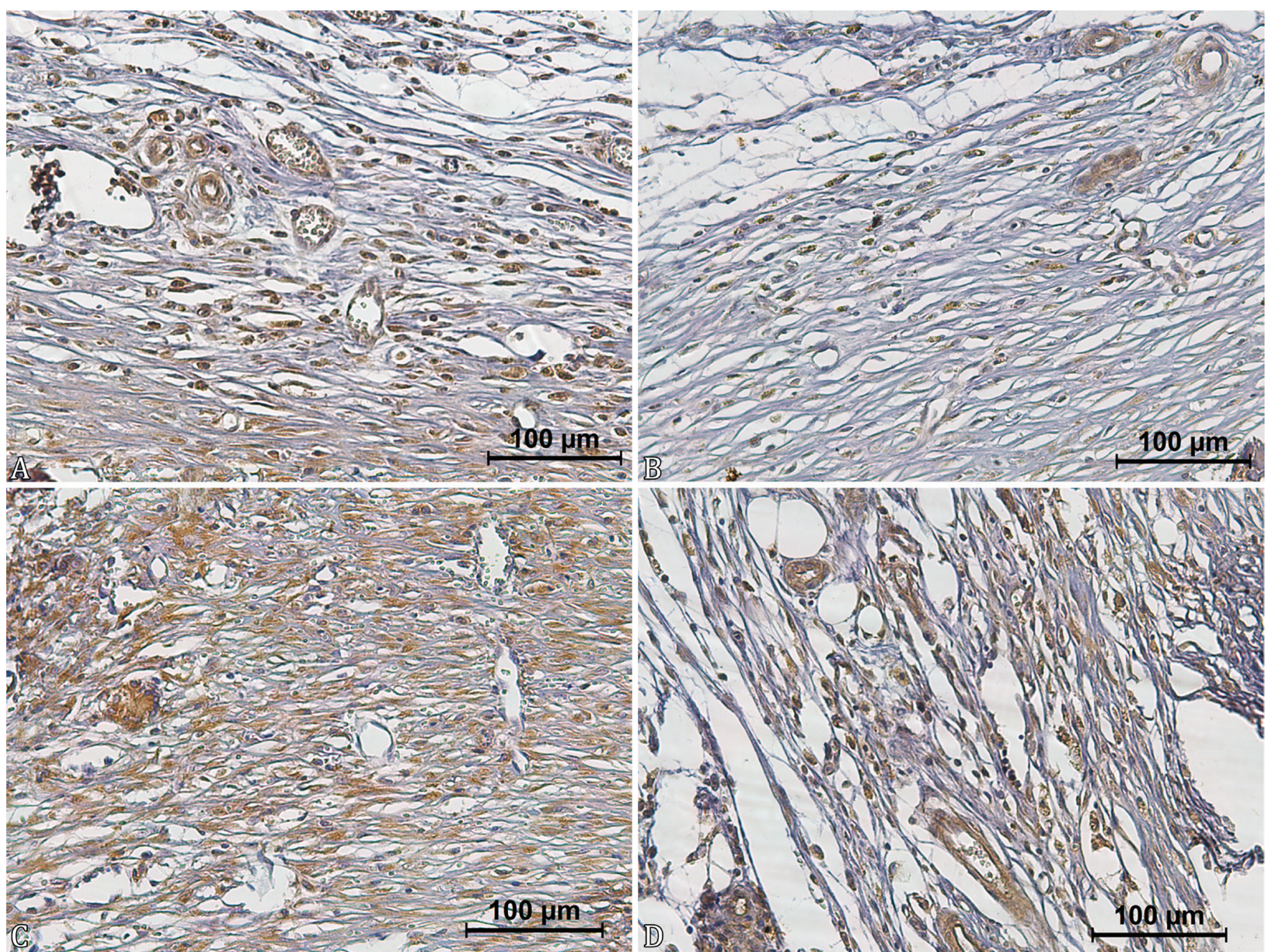

Fig.4. Photomicrographs of the skin of rats from different groups at 8 days after wound induction. (A) Group ozonized water (GA) showing moderate anti-VEGF immunostaining. IHC, obj.40x. (B) Group $0.9 \%$ sodium chloride (GCL) showing discreet anti-VEGF immunostaining. IHC, obj.40x. (C) Group ozonized oil (GO) showing marked anti-VEGF immunostaining. IHC, obj.40x. (D) Group 0.2\% allantoin cream (GAL) showing moderate anti-VEGF immunostaining. IHC, obj.40x. 
reported (Sakazaki et al. 2007). Thus, considering the results of this and other studies, knowing the peroxide concentration in the oil is of fundamental importance to justify possible beneficial effects or their absence. Considering the ozone action principle, an oil with low peroxide concentration may not produce sufficient oxidative reactions to activate organic biochemical pathways and trigger medicinal effects, and, on the contrary, high peroxide concentration may exceed the metabolic capacity of the organic antioxidant system, limiting the beneficial action of ozone. This hypothesis is based on a temporary situation of oxidative stress, with no deleterious effects, but enough to activate therapeutic responses in the body, which is considered the principle of ozone therapy (Bocci 2005). Therefore, considering the concentration of peroxides in the ozonized oil, there is a lack of standardization regarding the ideal concentration range to obtain the beneficial effects in each phase of wound healing.

Although no statistical differences were observed between groups for the analysis of the type of ECM and fibroblast population, treatments using ozonized solutions may help these variables. For example, an in vitro assay showed marked fibroblastic migration under the action of saline solution with ozone at a concentration of $8 \mathrm{mcg} / \mathrm{mL}$ (Borges et al. 2017). On the other hand, Xiao et al. (2017) pointed out that ozonized oil increases the fibroblast migration process and increases its activation during the first five days after lesion, corroborating the results of Kim et al. (2009), who found more fibroblasts and collagen fibers on Masson's trichrome staining at 7 days after wound induction. Also, Pai et al. (2014) identified higher tensile strength in wounds treated with ozonized oil, which is attributed to the highest levels of collagenization observed in these wounds.

In this sense, the analysis of picrosirius red staining showed that wounds of groups GA and GO exhibited higher total collagen deposition at 15 and 22 days, respectively. When analyzing the type of collagen involved, wounds of these same groups presented more type I collagen (mature) on these days. The good performance regarding fibroblast population and ECM deposition in ozone studies is explained by an increase in growth factors in tissues exposed to this molecule (Kim et al. 2009), such as PDGF, which promotes the migration and proliferation of fibroblasts and their differentiation into myofibroblasts. In addition, there is the transforming growth factor-beta (TGF- $\beta$ ), also a promoter of fibroblast proliferation and extracellular matrix production (Abbas \& Lichtmann 2013, DiPietro 2013, Kwan \& Tredget 2017). The dose of ozone supplied, either by ozonized water or by oil, interferes with the number of biochemical components, which may generate positive, placebo, or even harmful effects.

Wounds of the GO group showed, at all evaluated times, a higher blood vessel count when compared to wounds of other groups. This finding was more pronounced at 3 and 8 days when wounds of GO group had a higher average of neovascularization $(\mathrm{p}<0.05)$ than that found for $\mathrm{GCL}$, and at 15 days when GO wounds exhibited more neovessels than GCL and GAL. Groups GCL, GO, and GAL had a higher vascular count $(\mathrm{p}<0.05)$ when compared to GA at 22 days. Similarly, Valacchi et al. (2011) observed a higher angiogenesis index at 3 days after wound induction in groups treated with ozonized oil with a peroxide concentration from 949 to $3170 \mathrm{mEq} / \mathrm{kg}$. However, the highest degree of neovascularization was found in the group treated with oil at $1631 \mathrm{mEq} / \mathrm{kg}$ of peroxide at 7 and 14 days after wound induction and in the group treated with $3170 \mathrm{mEq} / \mathrm{kg}$ on day 14 . Therefore, by inferring that the concentration of peroxide in the oil used in this study $(418.48 \mathrm{mEq} / \mathrm{kg}$ ) had a positive impact on the increase of neovascularization in wounds compared to the other treatments, the therapeutic range of ozonized oil is still higher than that found in the literature is demonstrated, at least in relation to stimulating angiogenesis. In addition, the GA group was statistically similar to the treatment with ozonized oil at 3,8 , and 15 days, except on day 22, when it had a smaller amount $(p<0.05)$ when compared to other groups. Considering that at this moment of tissue repair there is a remodeling of scar tissue, this group was more advanced in the maturation and remodeling phases when compared to the others.

As with other growth factors, ozone therapy induces higher release of factors acting on neovascularization (Kim et al. 2009), such as PDGF and TGF- $\beta$, stimulating VEGF production, which is responsible for promoting migration and proliferation of endothelial cells, as well as vasodilation (Abbas \& Lichtmann 2013, DiPietro 2013, Kwan \& Tredget 2017). The immunohistochemical analysis of VEGF performed in this study is in accordance with this information, as wounds of GO group presented a higher intensity of this growth factor on all analyzed days. An experimental model (Krkl et al. 2016) using ozonized oil showed that the application of this therapy in skin flaps improved wound neovascularization in relation to the group treated with oil and the control group also due to the higher VEGF immunostaining in animals exposed to ozonized oil.

Ozone therapy has great potential in the context of skin wound repair. However, the technique remains controversial regarding its reliability among health professionals. It may be the translation of inconsistent results into empirical ozone treatments, reflecting the need to establish scientific criteria for treating wounds with ozonized solutions. In this sense, researches involving ozone therapy should be strictly controlled regarding the route of administration, vehicle, and concentration of ozone, which generate data that allow establishing protocols.

\section{CONCLUSION}

Ozonized water and oil at the tested concentrations favor the tissue repair process in experimentally induced skin wounds in rats. Ozonized water at $4.5 \mathrm{mcg} / \mathrm{mL}$ potentiates wound retraction and accelerates the onset of healing in the maturation and remodeling phase, while ozonized oil at a concentration of $418.48 \mathrm{mEq} / \mathrm{kg}$ of peroxides promotes higher neovascularization during tissue repair and higher deposition of type I collagen from the third week of treatment.

Acknowledgments.- To the School of Veterinary and Animal Science of Federal University of Goiás, "Fundação de Amparo à Pesquisa do Estado de Goiás” (FAPEG), "Coordenação de Aperfeiçoamento de Pessoal de Ensino Superior" (CAPES) and "Conselho Nacional de Desenvolvimento Científico e Tecnológico" (CNPq).

Conflict of interest statement.- The authors have no competing interests.

\section{REFERENCES}

Abbas A.K. \& Lichtmann A.H. 2013. Inflamação e reparo, p.29-73. In: Kumar V., Abbas A.K. \& Aster J.C. (Eds), Robbins Patologia Básica. 9ª ed. Elsevier, Rio de Janeiro. 
Araneda S., Commin L., Atlagich M., Kitahama K., Parraguez V.H., Pequignot J.M. \& Dalmaz Y. 2008. VEGF overexpression in the astroglial cells of rat brainstem following ozone exposure. Neurotoxicology 29(6):920-927. <https://dx.doi.org/10.1016/j.neuro.2008.09.006> <PMid:18848842>

Arnhold E. 2013. Package in the R environment for analysis of variance and complementary analyses. Braz. J. Vet. Res. Anim. Sci. 50(6):488-492. <https://dx.doi.org/10.11606/issn.1678-4456.v50i6p488-492>

Bocci V. 2005. Ozone: a new medical drug. Springer, Netherlands. 315p.

Borges G.Á., Elias S.T., Silva S.M., Magalhães P.O., Macedo S.B., Ribeiro A.P. \& Guerra E.N. 2017. In vitro evaluation of wound healing and antimicrobial potential of ozone therapy. J. Cranio-Maxillofacial Surg. 45(3):364-370. <https://dx.doi.org/10.1016/j.jcms.2017.01.005><PMid:28169044>

Brassolatti P., Bossini P.S., Oliveira M.C., Kido H.W., Tim C.R., Almeida-Lopes L., De Avó L.R., Araújo-Moreira F.M. \& Parizotto N.A. 2016. Comparative effects of two different doses of low-level laser therapy on wound healing third-degree burns in rats. Microsc. Res. Tech. 79(4):313-320. <https:// dx.doi.org/10.1002/jemt.22632><PMid:26853699>

DiPietro L.A. 2013. Angiogenesis and scar formation in healing wounds. Curr. Opin. Rheumatol. 25(1):87-91. <https://dx.doi.org/10.1097/ B0R.0b013e32835b13b6><PMid:23114588>

Filippi A. 2001. The influence of ozonised water on the epithelial wound healing process in the oral cavity. Dtsch Zahnarztl. 56.

Haddad M.A., Souza M.V., Hincapie J.J., Ribeiro Junior J.I., Ribeiro Filho J.D. \& Benjamin L.A. 2009. Comportamento de componentes bioquímicos do sangue em equinos submetidos à ozonioterapia. Arq. Bras. Med. Vet. Zootec. 61(3):539-546. <https://dx.doi.org/10.1590/S0102-09352009000300003>

Hao K., Li Y., Feng J., Zhang W., Zhang Y., Ma N., Zeng Q., Pang H., Wang C., Xiao L. \& He X. 2015. Ozone promotes regeneration by regulating the inflammatory response in zebrafish. Int. Immunopharmacol. 28(1):369-375. <https://dx.doi.org/10.1016/j.intimp.2015.05.026> <PMid:26033494>

Kim H.S., Noh S.U., Han Y.W., Kim K.M., Kang H., Kim H.O. \& Park Y.M. 2009. Therapeutic effects of topical application of ozone on acute cutaneous wound healing. J. Korean Med. Sci. 24(3):368-374. <https://dx.doi.org/10.3346/ jkms.2009.24.3.368><PMid:19543419>
Krkl C., Yigit M.V., Ozercan I.H., Aygen E., Gulturk B. \& Artas G. 2016. The effect of ozonated olive oil on neovascularization in an experimental skin flap model. Adv. Skin Wound Care 29(7):322-327. <https://dx.doi. org/10.1097/01.ASW.0000484172.04260.46><PMid:27300363>

Kwan P.O. \& Tredget E.E. 2017. Biological principles of scar and contracture. Hand Clin. 33(2):277-292.<https://dx.doi.org/10.1016/j.hcl.2016.12.004> <PMid:28363295>

Pai S.A., Gagangras S.A., Kulkarni S.S. \& Majumdar A.S. 2014. Potential of ozonated sesame oil to augment wound healing in rats. Indian J. Pharm. Sci. 76(1):87-92. <PMid:24799744>

Sakazaki F., Kataoka H., Okuno T., Ueno H., Semma M., Ichikawa A. \& Nakamuro K. 2007. Ozonated olive oil enhances the growth of granulation tissue in a mouse model of pressure ulcer. Ozone, Sci. Eng. 29(6):503-507.<https:// dx.doi.org/10.1080/01919510701618205>

Sechi L.A., Lezcano I., Nunez N., Espin M., Duprè I., Pinna A., Molicotti P., Fadda G. \& Zanetti S. 2011. Antibacterial activity of ozonized sunflower oil (Oleozon). J. Appl. Microbiol. 90(2):279-284. <https://dx.doi. org/10.1046/j.1365-2672.2001.01235.x><PMid:11168731>

Silva V.D.U., Rodriguez T.T., Rocha I.A., Xavier F.C., Dos Santos J.N., Cury P.R. \& Ramalho L.M. 2016. Laser phototherapy improves early stage of cutaneous wound healing of rats under hyperlipidic diet. Lasers Med. Sci. 31(7):1363-1370. <https://dx.doi.org/10.1007/s10103-016-1985-9> $<$ PMid:27412288>

Valacchi G., Lim Y., Belmonte G., Miracco C., Zanardi I., Bocci V. \& Travagli V. 2011. Ozonated sesame oil enhances cutaneous wound healing in SKH1 mice. Wound Repair Regen. 19(1):107-115. <https://dx.doi.org/10.1111/ j.1524-475X.2010.00649.X><PMid:21134039>

Xiao W., Tang H., Wu M., Liao Y., Li K., Li L. \& Xu X. 2017. Ozone oil promotes wound healing by increasing the migration of fibroblasts via PI3K/Akt/ mTOR signaling pathway. Biosci. Rep. 37(6):BSR20170658. <https:// dx.doi.org/10.1042/BSR20170658> <PMid:28864782>

Yucesoy T., Kutuk N., Canpolat D.G. \& Alkan A. 2017. Comparison of ozone and photo-biomodulation therapies on mental nerve injury in rats. J. Oral Maxillofac. Surg. 75(11):2323-2332. <https://dx.doi.org/10.1016/j. joms.2017.04.016><PMid:28529151> 